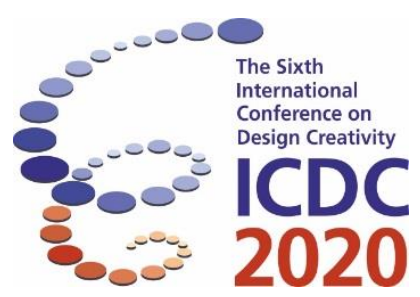

\title{
Understanding emotional responses and perception within new creative practices of biological materials
}

\author{
Nurul ‘Ayn Ahmad Sayuti ${ }^{12}$, Saeema Ahmed-Kristensen ${ }^{1}$ \\ ${ }^{1}$ School of Design, Royal College of Art, London, United Kingdom \\ ${ }^{2}$ Industrial Design Department, Faculty of Art \& Design, Universiti Teknologi MARA, \\ Malaysia
}

\begin{abstract}
There is an increasing trend for designers to use living systems, through biodesign and biophilia in the urban environment. As new creative processes emerge, the perception and emotional responses of users towards these new systems are somewhat unknown. This paper aims to study the emotional responses and perceptions towards biological materials that are embedded in existing product designs. Data was collected from 58 respondents through an online questionnaire. The findings from this exploratory study show that the significant differences by comparing the respondents with a background in design and non-design towards the level of desirability, practicality, aesthetically pleasing and the common use towards artificial and real biological materials. This paper extends existing understanding of perception and emotional responses to design incorporated living systems and can begin validating existing studies which have brought different perspectives towards the functions, practicality, aesthetical value and emotional attachments of products.
\end{abstract}

Keywords: biophilic design, biodesign, biological materials, emotional design, product design

\section{Introduction}

With the emergence of new biological materials in everyday designs, the perception of the products' functions, practicality, aesthetical value and emotional attachments formed are unknown. Design genre such as biophilic design, biodesign, bio-inspired design, biomimicry amongst other are growing areas encouraging the usage of biological materials. These are not only motivated to solve problems such as environmental impact but also expand the use of biological materials to the next level in product design development. The use of living biological elements are no longer restricted to the scientific field, but it has gone beyond to engineering and design with the incorporation of these living materials into the structures, objects and processes (Myers, 2018). The examples are circumventive organs by Agi Haines, Bioencryption, modified bacteria (Escherichia coli) encryption methods by School of Life sciences, Hong Kong and Lung-on-a-chip, microfluidic channels etched into a transparent polymer, human alveolus and endothelial cells by Donald E. Ingber and Dongeun Huh (Myers, 2018). Designers and scientists are eager to explore to produce and use more radical materials extending the norm of the everyday products used to be. This transition in the design field can no longer be ignored as the diversity of these cross fields encourage a more radical approach in design with biological materials moving to 
become a key component for both designers and scientists alike. Thus, this paper explores one aspect of the use of biophilic design and its perception; these are defined and briefly summarised here.

Biophilic design is the application of biophilia theory which were introduced by Fromm in 1973 and Wilson (1982) to the built environment by incorporating natural elements in the modern living or nonliving space. Nature plays a crucial role in the well-being of the human mind, emotion, and physical well-being (Kellert et al., 2008). Biophilic design has evolved and expanded into practical applications from Biophilia theory. Biodesign (Myers, 2018) is defined as the incorporation of living biological materials or ecosystems that enable the systems designed to be more renewable and sustainable.

Products can create an emotional attachment between the user and the objects. Norman (2004) discusses three levels of emotional response concerning objects, which are; (1) visceral level (2) behavioural level (3) reflective level. These three levels have been used to map product characteristics. Visceral design is the visual appearances that can be interpreted and first response; behavioural design is the effective performance, pleasurable usage of the product and the functionality, and reflective design involves the memories and understandings of the experience of satisfaction after using the product. Generally, emotion can be defined as subjective biological conscious or non-conscious expressions, which involve facial and vocal expressions, physiological symptoms and occur depending on specific events that can be experienced in daily life (Niedenthal et al., 2006). Moreover, Plutchik (2001) and Khalid and Helander (2006) stated that emotions involve human's internal stimulations and occur naturally while influencing the way human beings react, behave and think. This paper extends a study on emotional design and perception survey which were executed to gain feedback on positive and negative emotion towards the Furniture Designs embedded with Living Organisms (FDLOs) (Sayuti et al., 2015 and 2018). The new research, focus more on the application of the biological materials and designs that incorporate biological materials are further identified, where a new survey has been designed for this purpose.

Merleau-Ponty (2004), discussed perception by seeing the connection between the world of perception and the world of science, space, sensory objects, animal life, self and other people experienced, art and philosophy, and the world of classical and modern. Perez Mata et al. (2013, 2015) studied the perception of aesthetics in consumer products and used the categorising developed by Goldman (1995) to categorise the perceptions. Other studies that closely relate to the study of perception in design were conducted by Dunston et al. (2002), DiSalvo et al. (2002), and by Carozza (2016) about Augmented Reality Computer Aided Drawing (AR-CAD), a human-robot interaction was more focused on the initial understanding of facial features images of 48 humanoid robots and the design development of a cybernetic hand (prosthetic hand) devices.

In relation to new creative practices, the application of nature (biophilia) is not novel. Nature has been used directly or indirectly to enhance creativity towards areas such as education (Plambech and Van Den Bosch, 2015; Kiewra and Veselack, 2016), health (McCurdy et al.; 2010) business administration (Ceylan, Dul and Aytac, 2008) and among other fields. However, a deeper understanding of perception of biophilia, and biodesign is needed for these practices to be extended to the creative process of products. This paper found that the natural elements, be it artificial or real materials can elicit a positive or negative perception based on the desirability, practicality, aesthetically pleasing and familiarity in the everyday products.

\subsection{Research Aim}

The research aims to understand the impact of new emerging creative processes and their outcomes to end users. Specifically, the research investigates the emotional responses and perception of users to biophilic materials. In addition, how these emotional responses and perceptions are affected when the materials are embedded in a product will also be studied. This study will also further clarify the user perception toward biophilia, biophilic design and bio-design.

\section{Methodology}

This research project was developed in four stages, namely: 1) an initial compilation and classification of biological materials and related products were carried out, 2) the online survey was disseminated to understand the emotional responses and perception of potential consumers towards the biological 
elements, 3) the a further development of conceptual model from previous study and tested in the survey, 4) discussion on the early results gathered from the survey. This paper only summarises the main aspects of these four stages.

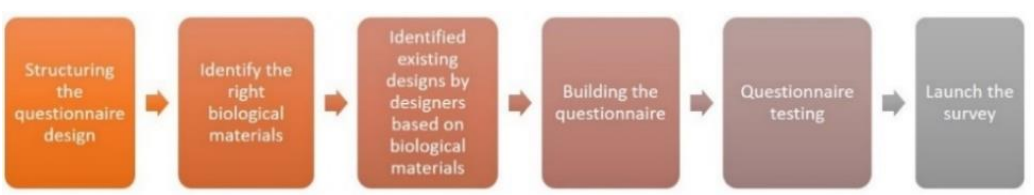

Figure 1: The Experimental Design Phases

A research framework was developed for the research project, Figure 1 shows the main phases in the experimental design. To develop the survey, the researchers first identified types of a living organism/ biological materials that are embedded into existing product designs. These biological materials were then categorised into four categories: 1) Artificial natural elements which consist of images of nature such as in photographs, graphics, painting, drawing and others and artificial plants, flowers or grass, 2) Real natural element: plants such as moss, edible plants, flowers and decorative plants and cacti or succulents, 3) Real natural element: animals which involve animals such as fishes, insects and other with due care and 4) Real natural element: microorganism such as fungi, algae and beneficial bacteria as can be seen in Figure 2 below.

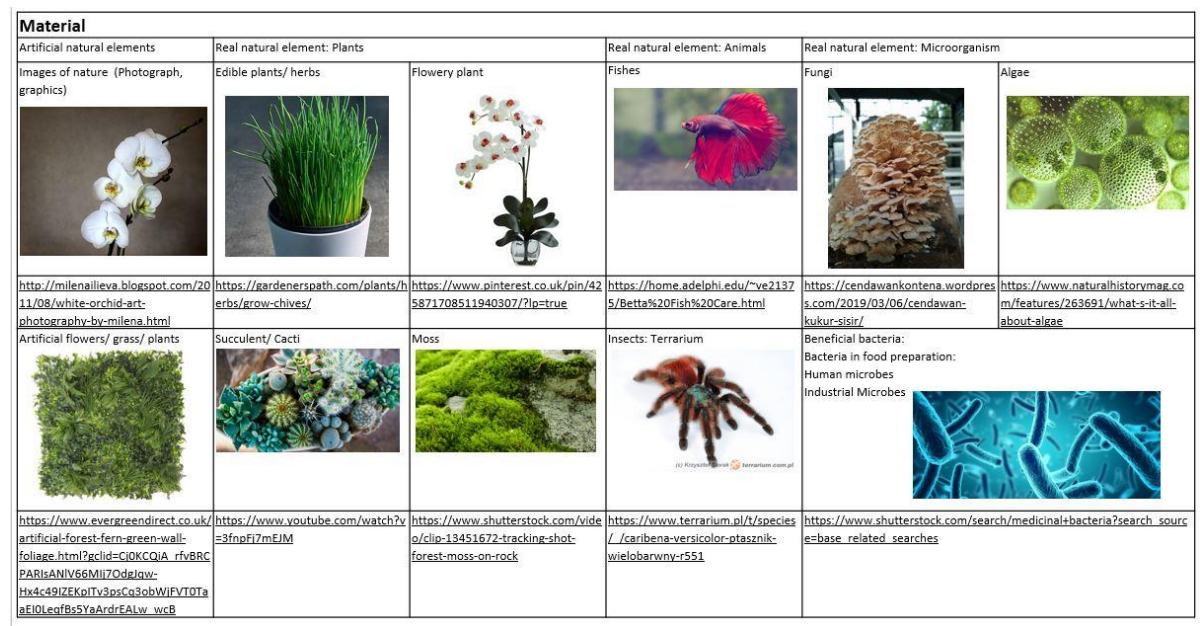

Figure 2: An example of artificial and real biological materials used in the survey

\subsection{Questionnaire design}

A survey was use to gather the respondent's perceptions and their emotions towards biological elements embedded in designs. The survey gathered data on how people or potential users perceive the biological elements in existing design objects and their emotional response, and how this is affected through the purpose of the object, emotion and the practical use in existing designs. The questionnaire was developed in order to gain feedback from the respondents. This consisted of 6 main sections: A) Respondent background, B) Artificial and real biological materials, C) Emotional Design: Biological Materials., D) The purpose of biological elements., E). Existing Biophilic Design/ Bio-design, and $F$. Biophilia, biophilic design, bio-inspired design and bio-design. The questionnaire consisted of visual imagery of biological materials and existing designs by selected designers, thus, no participants were exposed to any biomaterials. Participants were recruited through social media, and the survey was also disseminated through emails. Participation was voluntarily, and a participant could withdraw at any point in the survey. A total of 58 responses were collected and analysed for this paper.

There are at least ten assessment methods that have been developed or used widely in the design fields to measure emotion, which are 1) Likert Scales: which normally use 3-, 5- and 7-points or more (Matell and Jacoby, 1972; Albaum, 1997; Johns, 2010)., 2) semantic differential scale which was developed by 
Osgood (1940s to 1950s)., 3) Kansei engineering developed by Nagamachi (1995). 4) Self-Assessment Manikin (SAM) developed by Bradley and Lang (1994) is a method which assesses the pleasure, arousal, and dominance., 5) Positive Affect Negative Affect Schedule (PANAS) was developed by Watson et al. in 1988 to measure a person's positive mood and negative mood., 6) Products as Personalities is a questionnaire for measuring pleasure in products, developed by Jordan in 2000., 7) PrEmo is an abbreviation for Product Emotion Measurement Instrument (PrEmo) was developed by Desmet in 2003 (Desmet, 2003 and 2018; Laurans and Desmet, 2017)., 8) Product Personality Profiling (PPP) was developed by McDonagh et al. (2000)., 9) SEQUAMS: stands for Sensory Quality Assessment Method was developed by Bonapace in 2002., and finally 10) Product Personality Scale was developed by Mugge, Govers, Schoormans (2009). This study adopted PrEmo in order to measure the emotional responses and a likert scale to evaluate perceptions, using the approach of Perez Mata et al. $(2013,2015)$.

\section{Results}

\subsection{Respondent background}

A total of 58 responses were received and analysed for this paper. Background data were collected on Gender (70.7\% of female, $27.6 \%$ of male while $1.7 \%$ preferred not to answer), Age (ranging from $18-25$ with $8.6 \%, 26$ to 30 with $17.2 \%, 31$ to 40 with $43.1 \%$ is the highest responses received from, 41 to 50 with $27.6 \%$, while a minimum responses received from 51 to 60 with $1.7 \%$ and 61 or older with 1.7\%.). The respondents are from a Design and Non-design background with $46.6 \%$ and $53.4 \%$ respectively. Moreover, almost all participants stated they had access to nature with an overall $91.4 \%$.

\subsection{The perception of artificial and real biological materials was analysed}

Eleven (11) artificial and real biological materials were identified and used in the questionnaire (see Figure 2). The respondents were asked to use a 7- point Likert Scale to rate the level of desirability (undesirable), practicality (impractical), aesthetically pleasing (unpleasant aesthetically) and the common/ familiarity (uncommon) for the incorporation of artificial and biological materials into everyday products. The results can be seen in Table $1 \mathrm{a}$ and $\mathrm{b}-4 \mathrm{a}$ and $\mathrm{b}$ below are the descriptive analysis of the Mean value of the SPSS test. A mean score uses the scale of (-) 3; very, (-)2; quite, (-)1; slightly, 0; neutral, positive integers indicate an overall positive rating (e.g. desirable) and negative a negative rating (e.g. undesirable).

\subsubsection{Materials positive or desirable}

The desirability of the materials was analysed; the findings showed that 5 materials received a positive level of desirability are moss, edible plants, decorative plants, succulent and cacti and fishes. Three (3) materials received a negative level of desirability (i.e. perceived as undesirable), namely insects, algae, and bacteria. The responses were analysed to understand that there is a difference between designs and non-design background. The artificial plants received a negative response by the design background. Fungi was perceived as neither desirable or undesirable by both groups. Nature images was perceived as neutral by the design group. These results highlighted in grey in Table 1a below. The ANOVA test was applied to compare the significant differences in the Mean on the perception of two groups of respondents (comparing those with a background in design and not design), gender was not used as $70.7 \%$ were female for each of these. From Table $1.1 \mathrm{~b}$, the images of nature and artificial plants were found to have significantly different responses, i.e. Sig. value (below 0.05 ) with 0.03 and 0.007 respectively. It was surprising that the bacteria result was not significant given the growing use bacteria within biodesign; it was expected that designers would have a greater level of acceptance.

\subsubsection{Materials positive or practicality}

The findings showed that 4 materials were perceived to have a positive level of practicality: nature images, edible plants, decorative plants, succulents and cacti. Three (3) materials received negative levels of practicality (i.e. perceived as impractical), are insects, algae and bacteria. Moss and fungi were 
perceived as close to neutral (neither practical or impractical) by both groups. While artificial plants and fishes were viewed as close to neutral (neither practical or impractical) by the designers, these results highlighted in grey in Table 2a.

Table 1a: The analysis of Mean value on perception of desirability

\begin{tabular}{|c|c|c|c|c|c|c|c|c|c|c|c|c|}
\hline \multicolumn{2}{|c|}{ Working Background } & $\begin{array}{l}\text { Nature } \\
\text { Images }\end{array}$ & $\begin{array}{c}\text { Artificial } \\
\text { plants }\end{array}$ & Moss & $\begin{array}{l}\text { Edible } \\
\text { plants }\end{array}$ & $\begin{array}{l}\text { Decorative } \\
\text { plants }\end{array}$ & $\begin{array}{l}\text { Succulents } \\
\text { and Cacti }\end{array}$ & Fishes & Insects & Fungi & Algae & Bacteria \\
\hline \multirow{3}{*}{$\begin{array}{l}\text { Non- } \\
\text { design }\end{array}$} & Mean & 1.7097 & 1.0323 & 1.1613 & 1.9355 & 2.1613 & 1.8387 & 1.2581 & -0.8710 & 0.0968 & -0.5806 & -0.6452 \\
\hline & $\mathrm{N}$ & 31 & 31 & 31 & 31 & 31 & 31 & 31 & 31 & 31 & 31 & 31 \\
\hline & Std. Deviation & 1.18866 & 1.51622 & 1.48541 & 0.92864 & 0.86011 & 1.41649 & 1.59097 & 1.92773 & 1.79545 & 1.43235 & 1.92438 \\
\hline \multirow[t]{3}{*}{ Design } & Mean & 0.8148 & -0.2963 & 1.5185 & 2.0370 & 1.9259 & 2.0769 & 1.2963 & -0.4815 & 0.4815 & -0.1481 & -0.5926 \\
\hline & $\mathrm{N}$ & 27 & 27 & 27 & 27 & 27 & 26 & 27 & 27 & 27 & 27 & 27 \\
\hline & Std. Deviation & 1.84051 & 2.09054 & 1.45100 & 1.05544 & 1.49167 & 1.09263 & 1.61280 & 1.86816 & 1.39698 & 1.61015 & 1.52566 \\
\hline \multirow[t]{2}{*}{ Total } & Mean & 1.2931 & 0.4138 & 1.3276 & 1.9828 & 2.0517 & 1.9474 & 1.2759 & -0.6897 & 0.2759 & -0.3793 & -0.6207 \\
\hline & Std. Deviation & 1.57846 & 1.91058 & 1.46764 & 0.98215 & 1.19094 & 1.27365 & 1.58715 & 1.89373 & 1.61998 & 1.51978 & 1.73537 \\
\hline
\end{tabular}

Table 1b: The ANOVA test for desirability

\begin{tabular}{llcccc}
\hline & & Sum of Squares & df & Mean Square & S \\
Images of nature & Between Groups & 11.556 & 1 & 11.556 & 4.960 \\
& Within Groups & 130.461 & 56 & 2.330 & \\
& Total & 142.017 & 57 & & \\
Artificial plants & Between Groups & 25.472 & 1 & 25.472 & 7.812 \\
& Within Groups & 182.597 & 56 & 3.261 & 0.007 \\
& Total & 208.069 & 57 & & \\
\hline
\end{tabular}

Table 2a: The analysis of Mean value on perception of practicality

\begin{tabular}{|c|c|c|c|c|c|c|c|c|c|c|c|c|}
\hline \multicolumn{2}{|c|}{ Working Background } & $\begin{array}{l}\text { Nature } \\
\text { Images }\end{array}$ & $\begin{array}{l}\text { Artificial } \\
\text { plants }\end{array}$ & Moss & $\begin{array}{l}\text { Edible } \\
\text { plants }\end{array}$ & $\begin{array}{l}\text { Decorative } \\
\text { plants }\end{array}$ & $\begin{array}{l}\text { Succulents } \\
\text { and Cacti }\end{array}$ & Fishes & Insects & Fungi & Algae & Bacteria \\
\hline \multirow{3}{*}{$\begin{array}{l}\text { Non- } \\
\text { design }\end{array}$} & Mean & 1.5161 & 1.2258 & 0.6452 & 1.8710 & 1.7097 & 1.6667 & 1.0323 & -1.0000 & 0.1613 & -0.54839 & -0.7097 \\
\hline & $\mathrm{N}$ & 31 & 31 & 31 & 31 & 31 & 30 & 31 & 31 & 31 & 31 & 31 \\
\hline & Std. Deviation & 1.15097 & 1.23044 & 1.66430 & 1.05647 & 1.16027 & 1.47001 & 1.58080 & 1.77012 & 1.75303 & 1.433846 & 1.86536 \\
\hline \multirow[t]{3}{*}{ Design } & Mean & 1.1111 & 0.2222 & 0.3704 & 1.3333 & 1.0741 & 1.1481 & 0.1852 & -0.8889 & 0.1852 & 0.11111 & -0.2963 \\
\hline & $\mathrm{N}$ & 27 & 27 & 27 & 27 & 27 & 27 & 27 & 27 & 27 & 27 & 27 \\
\hline & $\begin{array}{l}\text { Std. Deviation } \\
\text { Mean }\end{array}$ & $\begin{array}{c}1.42325 \\
\mathbf{1 3 2 7 6}\end{array}$ & $\begin{array}{c}1.67179 \\
\mathbf{0 . 7 5 8 6}\end{array}$ & $\begin{array}{c}1.54791 \\
\mathbf{0 . 5 1 7 2}\end{array}$ & $\begin{array}{l}1.44115 \\
\mathbf{1 . 6 2 0 7}\end{array}$ & $\begin{array}{l}1.66239 \\
\mathbf{1 . 4 1 3 8}\end{array}$ & $\begin{array}{l}1.85439 \\
\mathbf{1 . 4 2 1 1}\end{array}$ & $\begin{array}{c}1.61810 \\
\mathbf{0 . 6 3 7 9}\end{array}$ & $\begin{array}{l}1.62512 \\
\mathbf{- 0 . 9 4 8 3}\end{array}$ & $\begin{array}{c}1.35978 \\
\mathbf{0 . 1 7 2 4}\end{array}$ & $\begin{array}{l}1.527525 \\
-\mathbf{0 . 2 4 1 3 8}\end{array}$ & $\begin{array}{l}1.46274 \\
\mathbf{- 0 . 5 1 7 2}\end{array}$ \\
\hline Total & Std. Deviation & 1.28947 & 1.52535 & 1.60308 & 1.26806 & 1.43923 & 1.66848 & 1.64048 & 1.69024 & 1.56875 & 1.502166 & 1.68836 \\
\hline
\end{tabular}

Artificial plants and fishes were found to have significantly different responses based upon the background of the participants, i.e. Sig. value (below 0.05 ) with 0.011 and 0.049 respectively (see Table $2 b)$. Those with design backgrounds perceived the use of artificial plants as neither practical or impractical, whereas the non-design perceived it as practical. Design background also perceived fishes as neither practical or impractical while non-design considered fishes as practical to be embedded in everyday products.

Table 2b: The ANOVA test for practicality

\begin{tabular}{llcccc}
\hline \multirow{3}{*}{ Artificial plants } & Sum of Squares & df & Mean Square & F \\
& Between Groups & 14.535 & 1 & 14.535 & 6.893 \\
& Within Groups & 118.086 & 56 & 2.109 & \\
Fishes & Total & 132.621 & 57 & & \\
& Between Groups & 10.355 & 1 & 10.355 & 4.054 \\
& Within Groups & 143.042 & 56 & 2.554 & 0.049 \\
& Total & 153.397 & 57 & & \\
\hline
\end{tabular}

\subsubsection{Materials positive or aesthetically pleasing}

From the analysis, 6 materials received a positive level of perception aesthetically pleasing; these were: images of nature, moss, edible plants, decorative plants, succulent and cacti and fishes. Three (3) materials received a negative level of aesthetically pleasing (i.e. perceived as unpleasing aesthetically) are insects, algae and bacteria. Artificial plants and fungi were perceived as close to neutral (neither pleasing aesthetically or unpleasing aesthetically) by both groups. Results are highlighted in grey as in 
Table 3a below. There was no significant difference between non-design and design backgrounds for aesthetic in ANOVA test, as all results were more than 0.05 .

Table 3a: The analysis of Mean value on perception of aesthetic

\begin{tabular}{|c|c|c|c|c|c|c|c|c|c|c|c|c|}
\hline \multicolumn{2}{|c|}{ Working Background } & $\begin{array}{l}\text { Nature } \\
\text { images }\end{array}$ & $\begin{array}{l}\text { Artificial } \\
\text { plants }\end{array}$ & Moss & $\begin{array}{l}\text { Edible } \\
\text { plants }\end{array}$ & $\begin{array}{c}\text { Decorative } \\
\text { plants }\end{array}$ & $\begin{array}{l}\text { Succulents } \\
\text { and Cacti }\end{array}$ & Fishes & Insects & Fungi & Algae & Bacteria \\
\hline \multirow{3}{*}{$\begin{array}{l}\text { Non- } \\
\text { design }\end{array}$} & Mean & 1.4516 & 0.8710 & 1.2667 & 1.7419 & 2.0645 & 1.9032 & 1.4667 & -0.8387 & 0.2581 & -0.2581 & -0.8387 \\
\hline & $\mathrm{N}$ & 31 & 31 & 30 & 31 & 31 & 31 & 30 & 31 & 31 & 31 & 31 \\
\hline & Std. Deviation & 1.20661 & 1.38424 & 1.31131 & 1.09446 & 0.96386 & 1.35043 & 1.47936 & 1.80918 & 1.75058 & 1.54850 & 1.82751 \\
\hline \multirow[t]{3}{*}{ Design } & Mean & 1.4444 & 0.2308 & 1.5556 & 2.0000 & 2.0370 & 1.6667 & 1.7407 & -0.3704 & 0.2963 & -0.0370 & -0.7407 \\
\hline & $\mathrm{N}$ & 27 & 26 & 27 & 27 & 27 & 27 & 27 & 27 & 27 & 27 & 27 \\
\hline & $\begin{array}{l}\text { Std. Deviation } \\
\text { Mean }\end{array}$ & $\begin{array}{c}1.42325 \\
\mathbf{1 . 4 4 8 3}\end{array}$ & $\begin{array}{c}1.81786 \\
\mathbf{0 . 5 7 8 9}\end{array}$ & $\begin{array}{c}1.31071 \\
\mathbf{1 . 4 0 3 5}\end{array}$ & $\begin{array}{c}0.96077 \\
\mathbf{1 . 8 6 2 1}\end{array}$ & $\begin{array}{c}1.28547 \\
\mathbf{2 . 0 5 1 7}\end{array}$ & $\begin{array}{c}1.46760 \\
\mathbf{1 . 7 9 3 1}\end{array}$ & $\begin{array}{c}1.19591 \\
\mathbf{1 . 5 9 6 5}\end{array}$ & $\begin{array}{l}1.66752 \\
-\mathbf{0 . 6 2 0 7}\end{array}$ & $\begin{array}{c}1.46274 \\
\mathbf{0 . 2 7 5 9}\end{array}$ & $\begin{array}{l}1.45395 \\
\mathbf{- 0 . 1 5 5 2}\end{array}$ & $\begin{array}{l}1.22765 \\
\mathbf{- 0 . 7 9 3 1}\end{array}$ \\
\hline Total & Std.Deviation. & 1.30010 & 1.61408 & 1.30739 & 1.03362 & 1.11485 & 1.39873 & 1.34774 & 1.74545 & 1.60911 & 1.49621 & 1.56450 \\
\hline
\end{tabular}

\subsubsection{Materials positive or common/familiarity}

The familiarity of the materials was analysed, the findings showed that 3 materials received a positive level of common/familiarity, these were unsurprising: nature images, edible plants and decorative plants. Four (4) materials received a negative level of familiarity (i.e. perceived as uncommon), such as insects, fungi, algae and bacteria. Moss received an uncommon response from the design group in contrast to the non-design, moss was perceived as close to neutral. Artificial plants, succulents and cacti and fishes were viewed as close to neutral (neither common and uncommon) by the designers. These results highlighted in grey as in Table 4a below.

Table 4a: The analysis of Mean value on perception of common/ familiarity

\begin{tabular}{|c|c|c|c|c|c|c|c|c|c|c|c|c|}
\hline \multicolumn{2}{|c|}{ Working Background } & $\begin{array}{l}\text { Nature } \\
\text { images }\end{array}$ & $\begin{array}{c}\text { Artificial } \\
\text { plants }\end{array}$ & Moss & $\begin{array}{l}\text { Edible } \\
\text { plants }\end{array}$ & $\begin{array}{l}\text { Decorative } \\
\text { plants }\end{array}$ & $\begin{array}{l}\text { Succulents } \\
\text { and Cacti }\end{array}$ & Fishes & Insects & Fungi & Algae & Bacteria \\
\hline \multirow{3}{*}{$\begin{array}{l}\text { Non- } \\
\text { design }\end{array}$} & Mean & 1.5161 & 1.2000 & 0.9000 & 1.5806 & 1.8387 & 1.6129 & 1.2258 & -0.6129 & -0.1333 & -0.4516 & -0.7097 \\
\hline & $\mathrm{N}$ & 31 & 30 & 30 & 31 & 31 & 31 & 31 & 31 & 30 & 31 & 31 \\
\hline & Std. Deviation & 1.06053 & 1.27035 & 1.32222 & 1.08855 & 1.00322 & 1.14535 & 1.38347 & 1.76404 & 1.50249 & 1.38657 & 2.01979 \\
\hline \multirow[t]{3}{*}{ Design } & Mean & 1.0741 & 0.4815 & -0.2593 & 1.0370 & 1.3333 & 0.7778 & 0.6667 & -1.1538 & -0.6667 & -0.8889 & -0.9630 \\
\hline & $\mathrm{N}$ & 27 & 27 & 27 & 27 & 27 & 27 & 27 & 26 & 27 & 27 & 27 \\
\hline & Std. Deviation & $\begin{array}{c}1.35663 \\
\mathbf{1 3 1 0 3}\end{array}$ & $\begin{array}{l}1.47727 \\
\mathbf{0 . 8 5 9 6}\end{array}$ & $\begin{array}{c}1.58339 \\
\mathbf{0 3 5 0 9}\end{array}$ & $\begin{array}{l}1.31505 \\
\mathbf{1 3 2 7 6}\end{array}$ & 1.59326 & 1.62512 & $\begin{array}{l}1.64083 \\
\mathbf{0 . 9 5 5}\end{array}$ & $\begin{array}{l}1.64176 \\
-\mathbf{0 . 8 5 9 6}\end{array}$ & $\begin{array}{l}1.44115 \\
-\mathbf{0} 3860\end{array}$ & $\begin{array}{l}1.45002 \\
-\mathbf{0 . 6 5 5 2}\end{array}$ & $\begin{array}{l}1.48016 \\
-0.8276\end{array}$ \\
\hline Total & Std.Deviation. & 1.21694 & 1.40711 & 1.55255 & 1.21955 & 1.32373 & 1.43934 & 1.52137 & 1.71588 & 1.48510 & 1.42104 & 1.77841 \\
\hline
\end{tabular}

Artificial plants, moss and fishes were found to have significantly different responses, i.e. Sig. value (below 0.05) with $0.053,0004$ and 0.026 respectively (please refer Table $4 b$ ). These materials are generally known or commonly used or incorporated in any product or urban environment/ living space.

Table 4b: The ANOVA test for familiarity

\begin{tabular}{|c|c|c|c|c|c|c|}
\hline & & Sum of Squares & df & Mean Square & $\mathbf{F}$ & Sig. \\
\hline \multirow[t]{3}{*}{ Artificial plants } & Between Groups & 7.336 & 1 & 7.336 & 3.897 & 0.053 \\
\hline & Within Groups & 103.541 & 55 & 1.883 & & \\
\hline & Total & 110.877 & 56 & & & \\
\hline \multirow[t]{3}{*}{ Moss } & Between Groups & 19.097 & 1 & 19.097 & 9.064 & 0.004 \\
\hline & Within Groups & 115.885 & 55 & 2.107 & & \\
\hline & Total & 134.982 & 56 & & & \\
\hline \multirow[t]{3}{*}{ Succulent and Cacti } & Between Groups & 10.065 & 1 & 10.065 & 5.218 & 0.026 \\
\hline & Within Groups & 108.022 & 56 & 1.929 & & \\
\hline & Total & 118.086 & 57 & & & \\
\hline
\end{tabular}

\section{Conclusions, discussion and future research}

Emerging creative practices have led to the exploring and usage of biological materials, where these materials provide practical usages and may offer aesthetical value promoting new experience and emotional empathy towards the natural surroundings. The exploratory study was conducted using an online questionnaire to investigate the perception of materials using biodesign or biophilia, and the acceptance of these creative outcomes. The methodology employed to gather data was a custom online survey as the main instrument to disseminate to potential consumers. The finding of these perception, 
can be inform the new creative approaches of new designs and materials, enable in data to be collected in larger numbers than other approaches. These studies were used as guidelines Gunn (2002), Roth (2006), Mahon-Haft and Dillman (2010), White and Gatersleben (2011) Hofelich Mohr, Sell and Lindsay and (2016).From the preliminary findings, the following materials: insects, algae and bacteria, were found to have a negative perception for desirability, practicality, aesthetics and familiarity. The background of the participants was also analysed to investigate the difference between a design or nondesign background. Some significant differences were found, for example, the desirability of artificial plants were perceived as undesirable, by those with a design background in contrast to those with a nondesign background where viewed it as desirable. This research is part of a longer project; future work includes understanding the perception of biological materials when exploring designing products for different purposes in practicality, aesthetic and experience. Furthermore, this project can also be explored further with the use of real living biological materials and embedded it to existing products to investigate the direct experience of living materials.

\section{References}

Albaum, G. (1997). The likert scale revisited: an alternate version. Journal of the Market Research Society, 39(2), 331-332.

Bonapace, L. (2002). Linking product properties to pleasure: the sensorial quality assessment method-SEQUAM. Pleasure with Products: Beyond Usability, 189-217.

Bradley, M. M., \& Lang, P. J. (1994). Measuring emotion: the self-assessment manikin and the semantic differential. Journal of Behavior Therapy and Experimental Psychiatry, 25(1), 49-59.

Carrozza, M. C., Cappiello, G., Micera, S., Edin, B. B., Beccai, L., \& Cipriani, C. (2006). Design of a cybernetic hand for perception and action. Biological Cybernetics, 95 (6), 629-644.

Ceylan, C., Dul, J., \& Aytac, S. (2008). Can the office environment stimulate a manager's creativity?. Human Factors and Ergonomics in Manufacturing \& Service Industries, 18(6), 589-602.

Desmet, P. M. (2003). A multilayered model of product emotions. The Design Journal, 6(2), 4-13.

Desmet, P.M.A. (2018). Measuring emotion: Development and application of an instrument to measure emotional responses to products. In: M.A. Blythe \& A.F. Monk (Eds.), Funology 2: from usability to enjoyment (pp. 391404). Springer Publishing.

Desmet, P. M., Hekkert, P., \& Jacobs, J. J. (2000). When a car makes you smile: development and application of an instrument to measure product emotions. Advances in Consumer research, 27(1).

Desmet, P. M. (2012). Faces of product pleasure: 25 positive emotions in human-product interactions. International Journal of Design, 6(2), 1-29.

Desmet, P. M., \& Pohlmeyer, A. E. (2013). Positive Design: An introduction to design for subjective well-being. International Journal of Design, 7(3), 5-19.

DiSalvo, C. F., Gemperle, F., Forlizzi, J., \& Kiesler, S. (2002). All robots are not created equal: the design and perception of humanoid robot heads. In 4th conference on Designing interactive systems: processes, practices, methods, and techniques.

Dunston, P., Wang, X., Billinghurst, M., \& Hampson, B. (2003). Mixed reality benefits for design perception. Nist Special Publication SP, 191-196.

Goldman, A. (1995) Aesthetic value. Westview Press, Colorado.

Gunn, H. (2002). Web-based surveys: Changing the survey process. First Monday, 7(12).

Hofelich Mohr, A., Sell, A., \& Lindsay, T. (2016). Thinking inside the box: Visual design of the response box affects creative divergent thinking in an online survey. Social Science Computer Review, 34(3), 347-359.

Johns, R. (2010). Likert items and scales. Survey Question Bank: Methods Fact Sheet, 1.

Jordan, P. W. (2002). The personalities of products. Pleasure with products: Beyond usability, 19-47.

Kellert, S. R., Heerwagen, J., \& Mador, M. (2008). Biophilic design: The theory, science and practice of bringing buildings to life. John Wiley \& Sons.

Khalid, H. M., \& Helander, M. G. (2006). Customer emotional needs in product design. Concurrent Engineering, 14(3), 197-206.

Kiewra, C., \& Veselack, E. (2016). Playing with Nature: Supporting Preschoolers' Creativity in Natural Outdoor Classrooms. International Journal of Early Childhood Environmental Education, 4(1), 70-95.

Kowaltowski, D. C., Bianchi, G., \& De Paiva, V. T. (2010). Methods that may stimulate creativity and their use in architectural design education. International Journal of Technology and Design Education, 20(4), 453-476. 
Laurans, G., \& Desmet, P.M.A. (2017). Developing 14 animated characters for non-verbal self-report of categorical emotions. Journal of Design Research, 15(3/4), 214-233.

Matell, M. S., \& Jacoby, J. (1972). Is there an optimal number of alternatives for likert-scale items? Effects of testing time and scale properties. Journal of Applied Psychology, 56(6), 506.

McDonagh-Philp, D., \& Lebbon, C. (2000). The emotional domain in product design. The Design Journal, 3(1), 31-43.

Merleau-Ponty, M., Davis, O., \& Baldwin, T. (2004). The world of perception. Cambridge Univ Press.

Mugge, R., Govers, P. C., \& Schoormans, J. P. (2009). The development and testing of a product personality scale. Design Studies, 30(3), 287-302.

Nagamachi, M. (1995). Kansei Engineering: A new ergonomic consumer-oriented technology for product development. International Journal of Industrial Ergonomics, 15(1), 3-11.

Mahon-Haft, T. A., \& Dillman, D. A. (2010). Does visual appeal matter? Effects of web survey aesthetics on survey quality. In Survey Research Methods (Vol. 4, No. 1, pp. 43-59).

McCurdy, L. E., Winterbottom, K. E., Mehta, S. S., \& Roberts, J. R. (2010). Using nature and outdoor activity to improve children's health. Current problems in pediatric and adolescent health care, 40(5), 102-117.

Myers, W. (2018). Bio design: nature, science creativity. Revised and expanded version. Thames and Hudson

Niedenthal, P. M., Krauth-Gruber, S., \& Ric, F. (2006). Psychology of emotion: Interpersonal, Experiential, and Cognitive Approaches. Psychology Press.

Norman, D. A. (2004). Emotional design: Why we love (or hate) everyday things. Basic Books.

Osgood, C. E. (1952). The nature and measurement of meaning. Psychological bulletin, 49(3), 197.

Osgood, C. E., \& Tannenbaum, P. H. (1955). The principle of congruity in the prediction of attitude change. Psychological review, 62(1), 42.

Osgood, C. E. (1962). Studies on the generality of affective meaning systems. American Psychologist, 17(1), 10. Pérez Mata, M., Ahmed-Kristensen, S., \& Yanagisawa, H. (2013). Perception of aesthetics in consumer products. In DS 75-7: Proceedings of the 19th International Conference on Engineering Design (ICED13), Design for Harmonies, Vol. 7: Human Behaviour in Design, Seoul, Korea, 19-22.08. 2013.

Perez Mata, M., \& Ahmed-Kristensen, S. (2015). Principles for designing for perception. In DS 80-9 Proceedings of the 20th International Conference on Engineering Design (ICED 15) Vol 9: User-Centred Design, Design of Socio-Technical systems, Milan, Italy, 27-30.07. 15 (pp. 239-248).

Plambech, T., \& Van Den Bosch, C. C. K. (2015). The impact of nature on creativity-A study among Danish creative professionals. Urban Forestry \& Urban Greening, 14(2), 255-263.

Plutchik, R. E., \& Conte, H. R. (1997). Circumplex models of personality and emotions. American Psychological Association.

Plutchik, R. (2001). The nature of emotions human emotions have deep evolutionary roots, a fact that may explain their complexity and provide tools for clinical practice. American Scientist, 89(4), 344-350.

Roth, M. (2006). Validating The Use of Internet Survey Techniques In Visual Landscape Assessment-An Empirical Study From Germany. Landscape and Urban Planning, 78(3), 179-192.

Sayuti, N., Montana-Hoyos, C., \& Bonollo, E. (2015). A study of furniture design incorporating living organisms with particular reference to biophilic and emotional design criteria. Academic Journal of Science, 4(1), 75-106. Sayuti, N. A. A., Montana-Hoyos, C., \& Bonollo, E. (2018). Biophilic Design: Why do designers incorporate living organisms in furniture design?. In Conference Procceding The Fifth International Conference on Design Creativity (ICDC2018). University of Bath, UK.

Watson, D., Clark, L. A., \& Tellegen, A. (1988). Development and validation of brief measures of positive and negative affect: the PANAS Scales. Journal of Personality and Social Psychology, 54(6), 1063.

White, E. V., \& Gatersleben, B. (2011). Greenery On Residential Buildings: Does It Affect Preferences and Perceptions of Beauty? Journal of Environmental Psychology, 31(1), 89-98.

Wilson, E. O. (1984). Biophilia. Harvard University Press 